\title{
SCREENING OF PEPPER (CAPSICUM L.) SEEDLINGS TOLERANCE TO LOW TEMPERATURE
}

\author{
RAJAMETOV Sherzod, National Institute of Horticultural $\&$ Herbal Science, Republic of Korea \\ YANG Eun Young*, National Institute of Horticultural $\&$ Herbal Science, Republic of Korea \\ CHO Myeong Cheol, National Institute of Horticultural \& Herbal Science, Republic of Korea \\ CHAE Soo Young, National Institute of Horticultural $\&$ Herbal Science, Republic of Korea \\ JEONG Hyo Bong, National Institute of Horticultural \& Herbal Science, Republic of Korea
}

This study was conducted on screening for 21 pepper genotypes tolerance to low temperature and their duration of survival in 3-4 (38 days after sowing), and 4-6 (47 days after sowing) true leaf seedling growth stages (LS). It was detected that response of seedlings on low temperature were different and ranged among the genotypes depends on growth stages. Seedlings in early 3-4 LS growth stage were more susceptible than 4-6 LS seedlings, where the first symptoms of leaf cold damages (LCD) were revealed within 7 days after treatment (DAT) and 12 DAT in pepper seedlings, respectively. There were identified that the susceptible genotypes in 3-4 LS can be tolerant in 4-6 LS, or show opposite pattern, where tolerant one in next the growth stage, plant becomes susceptible. Low temperature negative impact on chlorophyll content (CHL) in leaves, however depends on seedling growth stage and genotype might be ranged. The lowest content of CHL were observed in early growth 3-4 LS seedlings than 4-6 LS. And, it was revealed that cold susceptible pepper genotypes in which $\mathrm{CHL}$ reduced significantly during cold treatment, but showed good ability to recovery of CHL after treatment of seedlings in NT condition, whereas cold tolerant genotypes with high CHL content during low treatment, can reduce significantly of CHL after transfer of seedlings to NT condition for recovery. According to screening were selected relatively cold tolerant pepper genotypes LT8 and LT9 in early 3-4 LS, and LT8, LT13, LT18, LT20 and LT21 in 4-6 LS, where LCD were below 45 and 10\%, respectively.

Introduction. Temperature is one of the main environmental factors affecting vegetative and reproductive growth of plants. Low temperature stress is a major environmental factor in temperate zone and significantly contributes reduction in plants growth rate, pollen viability, photosynthesis, delays or destroy the metabolism activity, formation of leaf and flowers, number of flowers, flowering time, fruit set, fruit growth and so on, and plants have different abilities to deal with low temperatures $[1,4,6,7,17,20,21]$.

According to Hu et al., [10] cold stress in plants can be divided into two categories: chilling stress $\left(0-20{ }^{\circ} \mathrm{C}\right)$ and freezing stress $\left(<0{ }^{\circ} \mathrm{C}\right)$. Chillingsensitive plants, such as tomato, cucumber, and sweet pepper, can suffer from cold injury and reduced productivity when exposed to low temperature $\left(0-12{ }^{\circ} \mathrm{C}\right)$. Low night temperatures have also been reported to cause negative impacts on reproductive developmental processes leading to reduction in yield of vegetable peppers [16, 19]. Furthermore, cold stress generally results in poor germination, stunted seedlings, yellowing of leaves, withering and reduced tillering. Therefore, recently many research work were conducted to develop methods to screening tolerant plants from family Solanaceae into abiotic stress in early growth stages, such as cold $[2,5,11,12,13,15]$.

The main strategy of this study was screening and find out survival ability of pepper genotypes in early seedlings growth stages on low temperature tolerance and identified cold tolerant genotypes for applying in breeding program to develop cold tolerant cultivar.

Research methods. Experiments were done in National Institute of Horticultural and Herbal Science (South Korea), where twenty one pepper genotypes seeds were sown in 31 January of 2020 in plastic trays containing 1:1 sand: peat by volume and grown in a glass greenhouse $\left(26 / 18^{\circ} \mathrm{C} \mathrm{D} / \mathrm{N}\right)$. Seedlings were divided into two parts. First one part of seedlings with 3-4 true leaf stage- LS (38 days after sowing) and second part with 4-6 LS (47 days after sowing) on 8-10 seedlings each genotype transferred on 09 and 18 March 2020, respectively into growth chamber, where night and day temperatures were maintained at $5^{\circ} \mathrm{C}$, light intensity $800 \mu \mathrm{mol} \mathrm{m}^{-2} \mathrm{~s}^{-1}(12 / 12 \mathrm{~h})$ and relatively humidity was within $70 \%$. Pepper seedlings with 3-4 LS and 4-6 LS were treated during 25 days and 26 days, respectively. All seedlings after day of treatments (DAT) at low temperature were transferred into normal treatment (NT) condition for recovery during 7 days. Leaf cold damages 
(LCD) of pepper leaves were measured visual, where injured leaf part was calculated in \% and divided on 5 grades: grade 1, normal growth- no damage; grade 2 , fewer than $1 / 4$ of the leaves ( $>25 \%$ ) become lightly yellowed-whited or desiccated-dried; grade $3,1 / 4$ to $1 / 2$ of the leaves (from 25 to $50 \%$ ) become lightly yellowed-whited or desiccated-dried; grade $4,1 / 2$ to $3 / 4$ of the leaves (from 50 to $75 \%$ ) become yellowed-whited or desiccated-dried; grade 5, more than $3 / 4$ of the leaves $(>75 \%)$ become severely yellowed-whited or the whole plant dies. Chlorophyll content (CHL) in leaves of pepper seedlings were measured by SPAD meter (Konica Minolta, Japan). Statistical analysis was done with EXCEL 2016 (Microsoft, WA, USA).

Results. Screening of different pepper genotypes in seedling stages for cold tolerance at $5^{\circ} \mathrm{C}$ temperature condition showed that response of seedlings on cold stress treatment was ranged depends development stages of seedlings among genotypes.

First symptoms of leaf cold damages in pepper seedlings with 3-4 LS and 4-6 LS were determined within 7 and 12 DAT at low temperature, respectively. It means that duration of seedlings survival to low temperature among pepper genotypes can be increased with increases of age of seedlings.

In seedlings with 3-4 LS were identified relatively cold tolerant genotypes LT8 and LT9, where LCD not exceeded 30.0 and $44.4 \%$, and 62.5 and respectively after $25 \mathrm{DAT}$ at low temperature (Fig. 1). While, in this growth stage genotypes LT3 and LT6 distinguished as susceptible to low temperature on the $14^{\text {th }}$ DAT where it was lethal and critical period with 100\% LCD. There were not revealed increasing of LCD in cold tolerant genotypes LT8 and LT9 at recovery period in normal treatment condition.

However, LCD rate were increased after recovery of seedlings at NT condition during 7 days, where almost in all cold tolerant genotypes LCD increased from 1 to 3 times than LCD rate at low temperature (Fig. 3). Whereas, LCD significantly

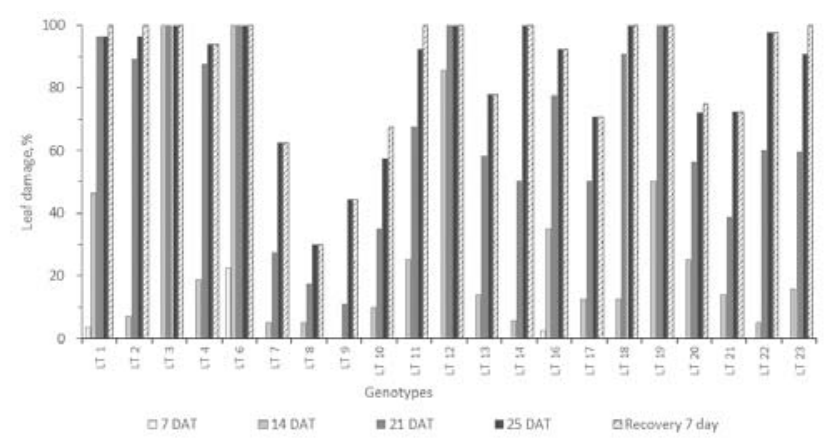

Figure 1. Changes of cold tolerance in pepper seedlings with 3-4 LS at low temperature reduced in cold susceptible genotypes LT1, LT4 and LT3 and showed highest recovery rate 50.0, 38.7 and $21.2 \%$, respectively than LCD on 26th DAT at low temperature.

Evaluation of changes of chlorophyll content in leaves under cold treatment condition showed that low temperature negative impact on $\mathrm{CHL}$ content, but depends on seedling growth stage and genotype might be ranged. So, the lowest content of CHL were observed in early growth 3-4 LS seedlings than 4-6 LS (Fig. 4). And, it was revealed the significant degradation of $\mathrm{CHL}$ among the seedlings 3-4 LS during treatment at low temperature, while in seedlings with 4-6 LS identified ranging of $\mathrm{CHL}$ values depending on treatment period and genotype (Fig. 5).

For example, in seedlings of genotypes LT7 and LT8 with 3-4 LS were determined increasing of CHL index and saved high content during 14 days at low treatment, and then it was reduced, but it could recover of CHL index on 10.7 and $11.5 \%$ higher compared with initial rate, respectively after 7 days of recovery at NT.

There were observed decreasing of $\mathrm{CHL}$ during 7 DAT in genotype LT20, but then again it started to increase and almost reached the initial rate in the end of investigation. Almost the same pattern were revealed in LT4 and LT14, but there was not find any significant relation between CHL and LCD among seedlings 3-4 LS. Whereas, shortly period of cold stress treatment induced a decrease of CHL in plant leaves [8, 13, 14]. However, in our previous studies confirmed that the CHL content in tomato accessions steadily increased and was relatively high among plants cultivated in low temperature than in normal temperature condition [17].

It is well known that CHL is important indicators of plant photosystem activity $[9,22]$ and play main role in synthesize organic matter and generate energy $[3,18]$. Therefore, it is interesting to observe the increased CHL contents among plants grown in low temperature even though photosynthesis was significantly reduced [17]. Further study necessary to clarify the relationship

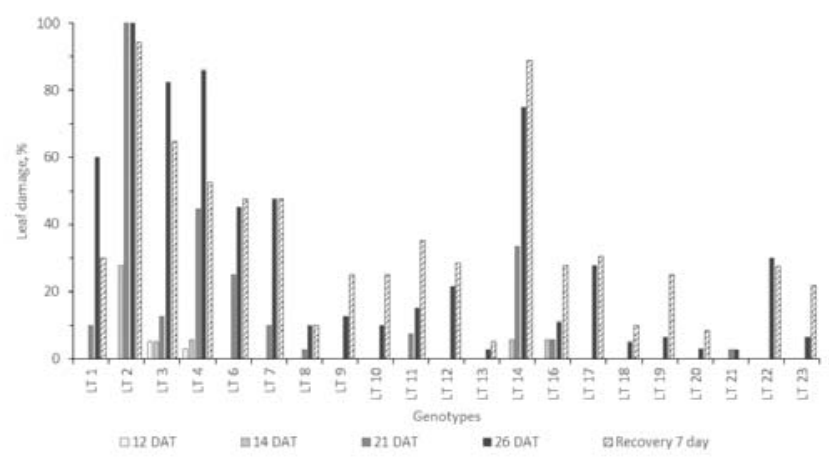

Figure 2. Changes of cold tolerance in pepper seedlings with 4-6 LS at low temperature 

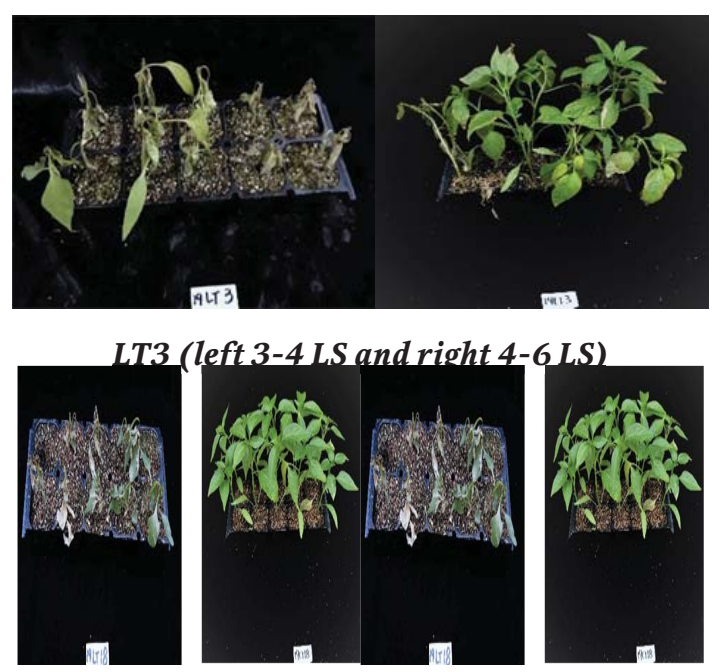

LT18 (left 3-4 LS and right 4-6 LS)

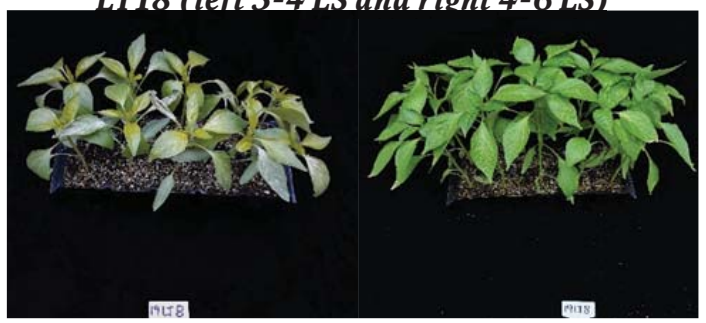

LT8 (left 3-4 LS and right 4-6 LS)

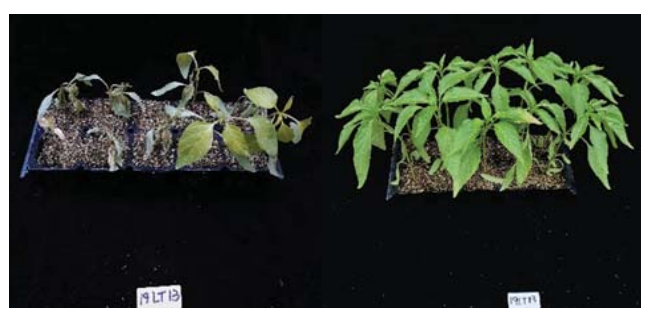

LT13 (left 3-4 LS and right 4-6 LS )

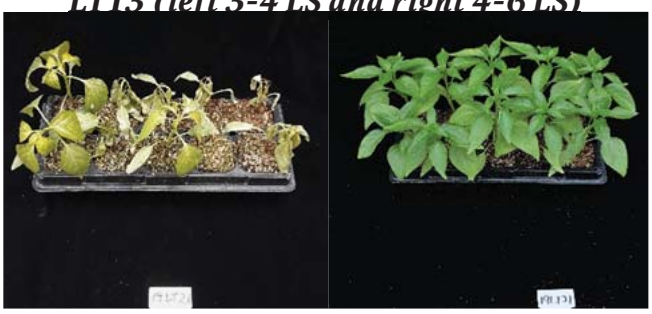

LT21 (left 3-4 LS and right 4-6 LS)

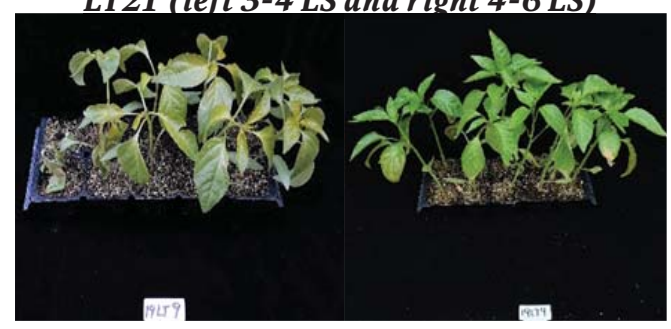

LT9 (left 3-4 LS and right 4-6 LS)

Figure 3. Changing of cold tolerance of pepper genotypes at different seedling development stages

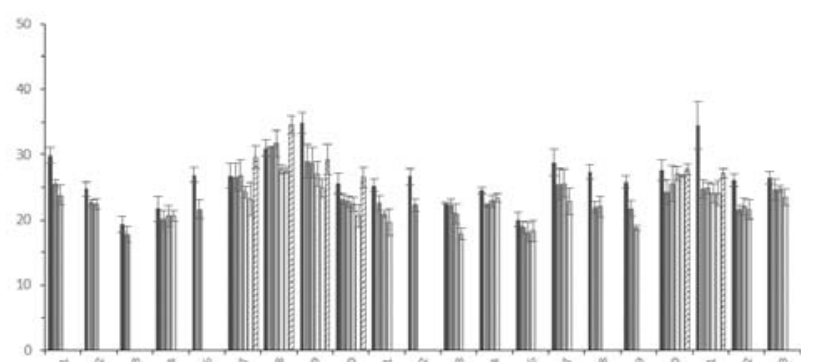

Figure 4. Changing of chlorophyll content in 3-4 LS seedlings at low temperature

between chlorophyll content and photosynthesis in low temperature condition. As was mentioned above, in seedlings of pepper genotypes in 4-6 LS were determined relatively high content of CHL and ranging depends on genotype than 3-4 LS at low temperature. So, the significantly high reduction of $\mathrm{CHL}$ in comparison with initial rate on 30.6 and $37.4 \%$ were revealed in genotypes LT8 and LT14 in the end of investigation on 26 DAT, respectively.

Genotypes LT19 and LT20 distinguished with significant high decreasing of CHL rate 18.3 and $23.0 \%$, respectively after 26 DAT at low temperature, but they could increase of CHL after recovery 7 days at NT condition, where index increased 36.6 and $25.5 \%$, respectively than initial CHL rate.

Conclusion. Results of screening of pepper genotypes based on the response of pepper genotypes to low temperature showed that response of seedlings on low temperature were

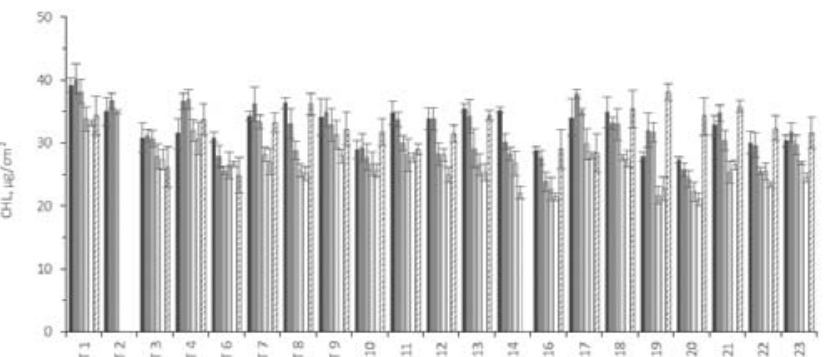

Figure 5. Changing of chlorophyll content in 4-6 LS seedlings at low temperature

different and ranged among the genotypes depends on growth stages. Duration of seedlings survival to low temperature among pepper genotypes were increased with increases of age of seedlings. The seedlings in early growth stages were more susceptible to negative temperature, where the first symptoms of leaf cold damages were revealed within 7 DAT in pepper seedlings with 3-4 true leaf growth stage (38 days after sowing), whereas in seedlings with 4-6 LS (47 days after sowing) were detected within 12 DAT. It was revealed that the susceptible genotypes at 3-4 LS can be tolerant in 4-6 LS, or show opposite pattern, where tolerant one in next the growth stage, plant becomes susceptible. Also, the same pattern was identified in evaluation of response of CHL content in leaves it can be ranged depends on growth stages and treatment periods.

However, it should be noted that cold susceptible pepper genotypes in which CHL reduced significantly during cold treatment, 
showed ability to recovery of CHL after treatment of seedlings at NT condition, whereas cold tolerant genotypes which had a high CHL during low treatment can reduce significantly of CHL after transfer of seedlings to NT condition for recovery.

Genotypes of pepper LT8 and LT9 with 3-4 LS, and LT8, LT13, LT18, LT20 and LT21 with 4-6 LS selected as cold tolerant, where LCD were below 45 and $10 \%$, respectively. However, in order to give a full assessment of tolerance selected pepper genotypes to low temperatures, further study of selected cold tolerant pepper genotypes development is necessary in the next reproductive organs development stages at low temperature cultivation.

Acknowledgments. This study was supported by a grant (Project No: PJ01267102 "Study on the physiological mechanism of temperature adaptable pepper lines") from National Institute of Horticultural and Herbal Science, Rural Development Administration.

\section{REFERENCES}

1. Adams S.R., Cockshull K.E., Cave C.R. Effect of temperature on the growth and development of tomato fruits // J. Ann. Bot., 2001, 88: 869-877.

2. Bhandari S.R., Kim Y.H., Lee J.G. Detection of temperature stress using chlorophyll fluorescence parameters and stress-related chlorophyll and proline content in paprika (Capsicum annuum L.) seedlings // J. Horticultural Science and Technology, 2018, 36(5): 619-629.

3. Caesar J. Effect of simulated shade radiation quality on the chlorophyll content of long and short shoot early leaves of birch (Betula pendula Roth.) // J. Photosynthetica, 1989a, 23: 126-129.

4. Chinnusamy V., Zhu J.K., Sunkar R. Gene regulation during cold stress acclimation in plants // Sunkar R. (Ed.). Plant Stress Tolerance, Springer, Heidelberg, 2010: 39-55.

5. Ding F., Liu B., Zhang Sh. Exogenous melatonin ameliorates cold-induced damage in tomato plants // J. Scientia Hortic, 2017, 219: 264-271.

6. Erickson A.N., Markhart A.H. Flower developmental stage and organ sensitivity of bell pepper (Capsicum annuum L.) to elevated temperature // J. Plant Cell Environ, 2002, 25: 123-130.

7. Gajanayake B., Trader B.W., Reddy K.R., Harkess R.L. Screening ornamental pepper cultivars for temperature tolerance using pollen and physiological parameters // J. Hortscience, 2011, 46(6): 878-884.

8. Ghorbanpour A., Salimi A. et al. The effect of Trichoderma harzianum in mitigating low temperature stress in tomato (Solanum lycopersicum L.) plants // J. Scientia Hortic, 2018, 230: 134-141.

9. Hernandez J., Jimenez A., Mullineaux P. Tolerance of pea (Pisum sativum L.) to long-term salt stress is associated with induction of antioxidant defences // J. Plant Cell Environ, 2000, 23: 853-862.

10. Hu T., Wang Y., Wang Q., Dang N., Wang L., Liu Ch., Zhu J., Zhan X.. The tomato 2-oxoglutarate-de- pendent dioxygenase gene SIF3HL is critical for chilling stress tolerance // J. Hortic. Res.,2019, 6: 45.

11. Liu H., Ouyang B., Zhang J., Wang T., Li H. et al. Differential modulation of photosynthesis, signaling, and transcriptional regulation between tolerant and sensitive tomato genotypes under cold stress // PLoS ONE, 2012, 7(11): e50785.

12. Liu H.Y., Wang Z.L., Wang Y.H. Studies on the chilling tolerance of different pepper varieties during germination of seeds and seedling // J. of Shihezi University, 2002, 6: 23-26.

13. Meng Y., Yan L., Fan Y. Study of low temperature and weak light on change of some electro-physiological index and its correlation with chilling injury index of sweet (hot) pepper seedlings // J. Botanical Research, 2017, 6(5): 333-339.

14. Munir S., Liu H., Xing Y., Hussain S., Ouyang B., Zhang Y., Li H., Ye Zh. Overexpression of calmodulinlike (ShCML44) stress-responsive gene from Solanum habrochaites enhances tolerance to multiple abiotic stresses // Sci. Rep., 2016, 6: 31772.

15. Park E., Hong S.J., Lee A.Y., Park J., Cho B.K., Kim G.. Phenotyping of Low-Temperature Stressed Pepper Seedlings Using Infrared Thermography // J. of Biosystems Engineering, 2017, 42(3): 163-169.

16. Pressman E., Shaked R., Firon N. Exposing pepper plants to high day temperatures prevents the adverse low night temperature symptoms // J. Physiol. Plant, 2006, 126: 618-626.

17. Rajametov Sh., Yang E.Y., Cho M.Ch., Chae S.Y., Kim J.H., Nam Ch.W., Chae W.B.. Traits affecting low temperature tolerance in tomato and its application to breeding program // J. Plant Breed. Biotech, 2019, 7 (4): 350-359

18. Richardson A.D., Duigan S.P., Berlyn G.P. An evaluation of noninvasive methods to estimate foliar chlorophyll content // J. New Phytologist, 2002, 153: 185-194.

19. Shaked R., Rosenfeld K., Pressman K. The effect of night temperature on carbohydrates metabolism in developing pollen grains of pepper in relation to their number and functioning // J. Sci. Hort., 2004, 102: 29-36.

20. Venema J.H., Posthumus F., de Vries M., van Hasselt P.R. Differential response of domestic and wild $L y c o-$ persicon species to chilling under low light: growth, carbohydrate content, photosynthesis and the xanthophyll cycle // J. Physiologia Plantarum, 1999, 105: 81-88.

21. Venema J.H., Linger P., van Heusden A.W., van Hasselt P.R., Bru "ggemann W. The inheritance of chilling tolerance in tomato (Lycopersicon spp.) // J. Plant Biology, 2005, 7: 118-130.

22. Xiaoa F., Yang Z., Zhua L. Low temperature and weak light affect greenhouse tomato growth and fruit quality // J. Plant Sci., 2018, 6(1): 16-24.

Rajametov Sherzod, Doctor of Philosophy, Postdoctoral researcher, Vegetable crops division, National Institute of Horticultural \& Herbal Science, Rural Development Administration, Wanju. Republic of Korea.

Yang Eun Young*, Doctor of Philosophy, Project manager, Vegetable crops division, National Institute of Horticultural \& Herbal Science, Rural Development Administration, Wanju. Republic of Korea.

Cho Myeong Cheol, Doctor of Philosophy, Team 
leader, Vegetable crops division,

Chae Soo Young, Senior researcher, Vegetable crops division, National Institute of Horticultural \& Herbal Science, Rural Development Administration, Wanju. Republic of Korea.

Jeong Hyo Bong, Senior researcher, Vegetable crops division, National Institute of Horticultural \& Herbal Science, Rural Development Administration, Wanju. Republic of Korea,
Wanju, Republic of Korea. National Institute of Horticultural \& Herbal Science, Rural Development Administration, Phone +8263-238-6613, E-mail: yangyang2@korea.kr

"Equal contribution and Correspondence: Yang Eun Young

Key words: genotype, seedlings, temperature, damage, chlorophyll,

\section{СКРИНИНГ РАССАДЫ ПЕРЦА ОСТРОГО (САРSICUM L.) НА ХОЛОДОСТОЙКОСТЬ}

Ражаметов Шерзод Нигматуллаевич, канд. с.-х. наук, докторант-исследователь, отдел овощных культур, Национальный научный институт плодоовощеводства и лекарственных растений, Администрация развития сельского хозяйства. Южная Корея.

Янг Ын- ёнг*, канд. с.-х. наук, руководитель проекта, отдел овощных культур, Национальный научный институт плодоовощеводства и лекарственных растений, Администрация развития сельского хозяйства. Южная Корея.

Чо Мёнг Чеол, канд. с.-х. наук, зав. отделом овощных культур, Национальный научный институт плодоовощеводства и лекарственных растений, Администрация развития сельского хозяйства. Южная Корея.

Чэ Су Ёнг, старший научный сотрудник, Отдел овощных культур, Национальный научный институт плодоовощеводства и лекарственных растений, Администрация развития сельского хозяйства. Южная Корея.

Жеонг Хё Бонг, старший научный сотрудник, отдел овощзых культур, Нацииональный научный институт плодоовощеводства и лекарственных растений, Администрация развития сельского хозяйства. Южная Корея.

* Корреспондент-автор: Янг Ын- Ёонг.

Ключевые слова: генотип; рассада,; температура; повреждение; хлорофилл.

В статье представлены результаты скрининга 21 генотипа перца острого в стадии формирование 3-4 (38 дней после посева) и 4-6 (47 дней после посева) настоящих листьев на холодостойкость и продолжительность их выживаемости при низкой температуре. Выявлено, что реакиия рассады периа острого к низким температурам различная и варируется по генотипам. Рассада в стадии 3-4 настоящих листьев более воспримчива к негативным температурам, чем в стадии 4-6 листьев: первые симптомы повреждение листьев от низкой температуры отмечено на седъмой и двенадцатый день обработки соответственно. Установлено, что воспримчивые генотипы в стадии 3-4 настоящих листьев могут быть устойчивыми в стадии 4-6 настоящих листьев или же наблюдается обратная картина, когда холодостойкий генотип может быть воспримчивым к низким температурам. Также пониженная температура негативно повлияла на содержание хлорофилла в листьях, при этом в зависимости от стадии развития рассады и генотипа оно менялось. Более низкий уровень содержание хлорофиллатомеченурассадывстадии 3-4настоящих листьев по сравнению срассадой, имеющей 4-6листьев. Отмечено, ито у слабоустойчивых генотипов в период выдержывание рассады при низкой температуре наблюдалось существенное снижение хлорофилла, но они показали хорошую способность его восстановления при культивировании рассады в нормальных условиях, тогда как у холодостойких генотипов отмечалось существенное снижение хлорофилла. Согласно результатом скрининга периа острого, в стадии развития 3-4 настоящих листьев были выявлены относительно холодостойкие генотипы перияа острого - LT8 и LT9 и в стадии 4-6 настоящих листъев - LT8, LT13, LT18, LT20 и LT21, у которых степень повреждение листьев от низкой температуры не превышала 45 и 10 \% соответственно. 